\title{
Analisis Pengaruh Kualitas Pelayanan Pajak, Sanksi Perpajakan, Dan Kesadaran Wajib Pajak Terhadap Kepatuhan Wajib Pajak Dalam Membayar Pajak Kendaraan Bermotor Pada Samsat Balaraja Banten
}

\author{
Khorida AR \\ khoridakampus@gmail.com \\ Fakultas Ekonomi dan Bisnis Universitas Muhammadiyah Tangerang \\ Armi Bakar \\ armibakar@gmail.com \\ Fakultas Ilmu Pendidikan dan Pengetahuan Sosial Unindra \\ Haryanto \\ ario_haryanto@yahoo.ac.id \\ Fakultas Ilmu Pendidikan dan Pengetahuan Sosial Unindra
}

\begin{abstract}
This research is in the form of a survey with the aim of analyzing the influence of Tax Service Quality, Tax Sanctions, and Taxpayer Awareness of Taxpayer Compliance in Paying Motor Vehicle Taxes. This study uses a survey method, with an affordable population is Taxpayer motor vehicle tax which is registered in the Office together with Samsat Balaraja with a sample of 100 motor vehicle taxpayers registered at the Samsat Balaraja Office. Data analysis uses multiple linear regression techniques. The study was conducted in September 2019 until December 2019. The results of this study indicate there is an influence on the quality of tax services, tax penalties, and awareness of taxpayers together on tax compliance in paying motor vehicle tax in Samsat Balaraja, this is evidenced by the acquisition Fcount $>$ Ftable or 10.004 $>2.696$ and sig $=0.000<\alpha=$ 0.05 .

Keywords: Tax Service Quality, Tax Sanctions, Taxpayer Awareness, Taxpayer Compliance

Abstrak

Penelitian ini berupa sebuah survey dengan tujuan menganalisis Pengaruh Kualitas Pelayanan Pajak, Sanksi Perpajakan, dan Kesadaran Wajib Pajak terhadap Kepatuhan Wajib Pajak dalam Membayar Pajak Kendaraan Bermotor. Penelitian ini menggunakan metode survey, dengan populasi terjangkau adalah WP pajak kendaraan bermotor yang terdaftar di Kantor bersama Samsat Balaraja dengan sampel 100 wajib pajak kendaraan bermotor yang terdaftar di Kantor Samsat Balaraja. Analisis data menggunakan teknik regresi linier berganda. Penelitian dilaksanakan pada bulan September 2019 sampai dengan bulan Dsember 2019. Hasil penelitian ini menunjukkan ada pengaruh kualitas pelayanan pajak, sanksi perpajakan, dan kesadaran wajib pajak bersama-sama terhadap kepatuhan wajib pajak dalam membayar pajak kendaraan bermotor di Samsat Balaraja, hal ini dibuktikan dengan perolehan nilai Fhitung $>$ Ftabel atau $10,004>2,696$ dan nilai sig $=0,000<\alpha=0,05$.
\end{abstract}

Kata kunci : Kualitas Pelayanan Pajak, Sanksi Perpajakan, Kesadaran Wajib Pajak, Kepatuhan Wajib Pajak 


\section{PENDAHULUAN}

Sumber dana utama pemerintah berupa penerimaan dari sektor pajak, untuk penyelenggaraan pemerintahan dalam pelayanan umum dan pembangunan nasional banyak didanai dari sektor pajak. Hampir seluruh wilayah di Indonesia menggali potensi pendapatan daerahnya melalui pajak daerah, karenanya pemerintah daerah harus berusaha meningkatkan sumber potensi pendapatan daerahnya, yang salah satunya adalah pajak kendaraan bermotor. Pajak kendaraan bermotor adalah pajak atas kepemilikan dan atau penguasaan kendaraan bermotor.

Kepatuhan pajak adalah suatu sikap terhadap fungsi pajak, berupa konstalasi dari komponen kognitif, efektif, dan konatif yang berinteraksi dalam memahami, merasakan dan berperilaku terhadap makna dan fungsi pajak, kepatuhan wajib pajak dapat ditingkatkan dengan meningktkan kesadaran wajib pajak, kualitas pelayanan, dan sanksi perpajakan.

Kesadaran wajib pajak masih sangat rendah, dapat dilihat dari jumlah tunggakan dan denda PKB di Kantor Bersama Samsat Balaraja. Jumlah penerimaan Pajak Kendaraan Bermotor dan perkembangan jumlah kendaraan bermotor mengalami peningkatan namun tidak diimbangi dengan kesadaran dan kepatuhan wajib pajak terhadap pemenuhan kewajibannya dalam membayar pajak, yang tercermin dari jumlah tunggakan dan denda yang cukup besar pada Kantor Bersama Samsat Balaraja.

Memberikan pelayanan yang baik dapat meningkatkan kepatuhan dari wajib pajak . Apabila petugas Samsat Balaraja bisa memberikan pelayanan publik secara transparan dan terbuka, hal tersebut dapat mempengaruhi sumber potensi penerimaannya. Untuk mencapai pelayanan publik yang baik Kementerian Pendayagunaan Aparatur Negara menyusun standar pelayanan publik bagi instansi pemerintah dengan mengeluarkan Keputusan Menteri Pendayagunaan Aparatur Negara No. 63/Kep/M.PAN/7/2003 tentang Pedoman Umum Penyelenggaraan Pelayanan Publik, dimana ketentuan umum pelayanan publik digariskan agar dapat dijadikan pedoman pelayanan baik oleh instansi pemerintah di pusat maupun di daerah

\section{LANDASAN TEORI Pengertian Pajak}

Menurut Undang-Undang No. 28 Tahun 2007 pasal 1 ayat 1 pajak adalah kontribusi wajib kepada negara yang terutang oleh orang pribadi atau badan yang bersifat memaksa berdasarkan Undang-Undang, dengan tidak mendapatkan imbalan secara langsung dan digunakan untuk keperluan negara bagi sebesar-besarnya kemakmuran rakyat. Menurut Mardiasmo (2012) pajak adalah iuran rakyat kepada kas Negara berdasarkan undang-undang (yang dapat dipaksakan) dengan tiada mendapat jasa timbal (kontra prestasi) yang langsung dapat ditunjukkan dan yang digunakan untuk membayar pengeluaran umum. Menurut Waluyo (2012) pajak adalah iuran kepada negara (yang dapat dipaksakan) yang terutang oleh yang wajib membayarnya menurut peraturan peraturan, dengan tidak mendapat prestasi kembali, yang langsung dapat ditunjuk, dan yang gunanya adalah untuk membiayai pengeluaran - pengeluaran umum berhubungan dengan tugas negara yang menyelenggarakan pemerintahan. 


\section{Theory of Planned Behavior}

Kajian dalam bidang psikologi mengenai faktor yang mempengaruhi perilaku kepatuhan pajak, salah satunya adalah melalui Theory of Planned Behavior. Ajzen dalam Hidayat (2013) dalam Theory of Planned Behavior (TPB) dijelaskan bahwa perilaku yang ditimbulkan oleh individu muncul karena adanya niat untuk berperilaku. Niat untuk berperilaku dipengaruhi oleh tiga factor sebagai berikut:

a. Behavioral belief

Keyakinan individu akan hasil dari suatu perilaku (outcome belief) dan evaluasi terhadap hasil dari keyakinan tersebut. Keyakinan dan evaluasi terhadap hasil ini akan membentuk variabel sikap (attitude).

b. Normatif belief

Keyakinan individu tentang harapan normatif orang lain yang menjadi rujukannya, seperti keluarga, teman, dan konsultan pajak serta motivasi untuk mencapai harapan tersebut. Harapan normatif ini membentuk veriabel norma subjektif (subjective norm).

c. Control belief

Keyakinan individu tentang keberadaan hal-hal yang mendukung atau menghambat perilakunya dan persepsinya tentang seberapa kuat hal-hal tersebut mempengaruhi perilakunya. Control belief membentuk variabel kontrol perilaku yang dipersepsikan (perceived behavioral control).

Theory of Planned of Behavior relevan untuk menjelaskan perilaku wajib pajak dalam memenuhi kewajiban perpajakannya.

\section{Kepatuhan Wajib Pajak}

Menurut Rahayu (2013) kepatuhan wajib pajak dapat didefinisikan sebagai suatu keadaan dimana wajib pajak memenuhi semua kewajiban perpajakan dan melaksanakan hak perpajakannya. Kiryanto (2010) menjelaskan bahwa kepatuhan wajib pajak merupakan suatu ketaatan untuk melakukan ketentuan-ketentuan atau aturanaturan perpajakan yang diwajibkan atau diharuskan untuk dilaksanakan. Menurut Muliari (2011) kepatuhan wajib pajak didefinisikan sebagai suatu keadaan dimana Wajib Pajak memenuhi semua kewajiban perpajakan dan melaksanakan hak perpajakannya

\section{Kualitas Pelayanan Pajak}

Burhanudin (2010) menyatakan kualitas pelayanan pajak merupakan suatu sikap atau pertimbangan global tentang keuangan dari suatu pelayanan pajak. Menurut Tjiptono (2005) mendefinisikan kualitas pelayanan pajak adalah tingkat keunggulan (excellence) yang diharapkan dan pengendalian atas tingkat keunggulan tersebut untuk memenuhi keinginan Wajib Pajak. Menurut Ellitan dan Anatan (2007) kualitas pelayanan pajak merupakan sebagai ukuran seberapa bagus tingkat layanan yang diberikan mampu menyesuaikan dengan ekspektasi wajib pajak, jadi kualitas pelayanan pajak diwujudkan melalui pemenuhan kebutuhan dan keinginan wajib pajak serta ketetapan penyampaian pelayanan tersebut.

\section{Sanksi Perpajakan}


Menurut Mardiasmo (2012) Sanksi perpajakan merupakan jaminan bahwa ketentuan peraturan perundang-undangan perpajakan (norma perpajakan) akan dituruti/ditaati/dipatuhi. Atau dengan kata lain sanksi perpajakan merupakan alat pencegah (preventif) agar Wajib Pajak tidak melanggar norma perpajakan. Menurut Waluyo (2012) sanksi perpajakan merupakan pemberian sanksi bagi wajib pajak yang tidak memenuhi kewajibannya sesuai dengan ketentuan peraturan perundang-undangan perpajakan yang berlaku. Muliari dan Setiawan (2010) menjelaskan bahwa sanksi perpajakan merupakan jaminan bahwa ketentuan peraturan perundang-undangan perpajakan (norma perpajakan) akan dituruti/ ditaati/ dipatuhi, dengan kata lain sanksi perpajakan merupakan alat pencegah agar wajib pajak tidak melanggar norma perpajakan. Jadi sanksi perpajakan merupakan pemberian sanksi bagi wajib pajak yang tidak memenuhi kewajibannya sesuai dengan ketentuan peraturan perundang-undangan perpajakan yang berlaku.

\section{Kesadaran Wajib Pajak}

Menurut Putri dan Jati (2012) kesadaran wajib pajak merupakan kondisi dimana wajib pajak tersebut memahami dan melaksanakan aturan perpajakan dengan benar dan sukarela. Hidayati (2014) kesadaran wajib pajak adalah perilaku Wajib Pajak berupa cerminan atau perasaan yang melibatkan pengetahuan, keyakinan dan penalaran disertai dengan adanya kecenderungan untuk bertindak sesuai stimulus yang diberikan oleh sistem dan ketentuan pajak tersebut. Muliari dan Ery (2009) kesadaran wajib pajak merupakan sebuah itikad baik seseorang untuk memenuhi kewajiban membayar pajak berdasarkan hati nuraninya yang tulus ikhlas. Semakin tinggi tingkat kesadaran wajib pajak, maka pemahaman dan pelaksanaan kewajiban perpajakan semakin baik sehingga dapat meningkatkan kepatuhan. Jadi kesadaran wajib pajak adalah keadaan dimana wajib pajak dapat memahami kewajiban perpajakannya.

\section{METODOLOGI PENELITIAN}

Penelitian ini menggunakan metode survey. Penelitian survey adalah penelitian yang dilakukan pada populasi besar maupun populasi kecil, tapi data-data yang dianalisis adalah data sampel yang diambil dari populasi, sehingga ditemukan kejadian-kejadian distribusi relative, dan hubungan antar variabel maupun psikologir. Penelitian survey dilakukan untuk mengambil suatu generalisasi yang dilakukan dengan menggunakan sampel representative. Menurut Sugiono (2014) Jenis penelitian survey terdiri dari beberapa langkah: (1) Penjajakan (eksploratif) (2) Diskriptif, (3) Penjelasan, (4) Evaliasi, (5) Prediksi (peramalan), (6) Penelitian operasional, dan (7) Pengembangan indikatorindikator social

Adapun analisis data dengan menggunakan analisis regresi berganda untuk melihat pengaruh antara dua variabel bebas atau lebih dengan satu variabel terikat. Dalam penelitian ini terdapat 3 variabel bebas yaitu: Kualitas Pelayanan Pajak (X1), Sanksi Perpajakan (X2), Kesadaran Wajib Pajak (X3), dan satu variabel terikat yaiyu: Kepatuhan Wajib Pajak (Y). Data-data yang ada dalam penelitian ini diperoleh melalui angket yang disebar kepada wajib pajak kendaraan bermotor di Samsat Balaraja.

Adapun persamaan regresi berganda yang digunakan sebagai alat analisis pada penelitian ini adalah: 


$$
\mathrm{Y}=\alpha+\beta 1 \mathrm{X} 1+\beta 2 \mathrm{X} 2+\beta 3 \mathrm{X} 3+\beta 4 \mathrm{X} 4+\varepsilon
$$

\section{HASIL PENELITIAN DAN PEMBAHASAN}

\section{Uji Validitas dan Reliabilitas}

\section{Uji Validitas}

Pengujian validitas dilakukan dengan bantuan komputer menggunakan program SPSS for Windows Versi 23. Dalam penelitian ini pengujian validitas hanya dilakukan terhadap 100 responden. Pengambilan keputusan berdasarkan pada nilai $r$ hitung (Corrected Item-Total Correlation) $>\mathrm{r}$ tabel sebesar 0,165, untuk df sebesar $100-2=$ $98 ; \alpha$ 0,05 maka item atau pertanyaan tersebut valid atau sebaliknya.

Tabel 1

Uji Validitas Kualitas Pelayanan Pajak (X1)

\section{Item-Total Statistics}

\begin{tabular}{|l|r|r|r|r|}
\hline & $\begin{array}{c}\text { Scale Mean } \\
\text { if Item } \\
\text { Deleted }\end{array}$ & $\begin{array}{c}\text { Scale } \\
\text { Variance if } \\
\text { Item Deleted }\end{array}$ & $\begin{array}{c}\text { Corrected } \\
\text { Item-Total } \\
\text { Correlation }\end{array}$ & $\begin{array}{c}\text { Cronbach's } \\
\text { Alpha if } \\
\text { Item Deleted }\end{array}$ \\
\hline KP1 & 31,29 & 4,612 &, 327 &, 674 \\
KP2 & 31,63 & 4,013 &, 407 &, 641 \\
KP3 & 31,74 & 4,073 &, 479 &, 621 \\
KP4 & 31,48 & 4,656 &, 236 &, 697 \\
KP5 & 18,02 & 1,353 & 1,000 &, 233 \\
\hline
\end{tabular}

Sumber : Data yang diolah, 2019

Berdasarkan tabel 1 maka dapat dilihat bahwa seluruh pernyataan untuk variabel metode kualitas pelayanan pajak memiliki status valid, karena nilai $r$ hitung ( Connected Item Total Correlation > $\mathrm{r}$ tabel sebesar 0,165)

Tabel 2

Uji Validitas Sanksi Perpajakan (X2)

\section{Item-Total Statistics}

\begin{tabular}{|c|c|c|c|c|}
\hline & $\begin{array}{c}\text { Scale Mean if } \\
\text { Item Deleted }\end{array}$ & $\begin{array}{c}\text { Scale } \\
\text { Variance if } \\
\text { Item Deleted }\end{array}$ & $\begin{array}{c}\text { Corrected } \\
\text { Item-Total } \\
\text { Correlation }\end{array}$ & $\begin{array}{c}\text { Cronbach's } \\
\text { Alpha if Item } \\
\text { Deleted }\end{array}$ \\
\hline SP1 & 38,85 & 10,755 &, 246 &, 694 \\
SP2 & 38,95 & 9,907 &, 582 &, 617
\end{tabular}




\begin{tabular}{|l|l|l|l|l|} 
SP3 & 38,79 & 10,349 &, 476 &, 642 \\
SP4 & 38,75 & 10,048 &, 452 &, 641 \\
SP5 & 38,34 & 12,105 &, 167 &, 710 \\
SP6 & 21,52 & 3,181 & 1,000 &, 361 \\
\hline
\end{tabular}

Sumber : Data yang diolah, 2019

Berdasarkan tabel 2 maka dapat dilihat bahwa seluruh pernyataan untuk variabel metode Sanksi Perpajakan memiliki status valid, karena nilai $r$ hitung ( Connected Item Total Correlation > $\mathrm{r}$ tabel sebesar 0,165

Tabel 3

Uji Validitas Kesadaran Wajib Pajak (X3)

Item-Total Statistics

\begin{tabular}{|l|r|r|r|r|}
\hline & $\begin{array}{c}\text { Scale Mean } \\
\text { if Item } \\
\text { Deleted }\end{array}$ & $\begin{array}{c}\text { Scale } \\
\text { Variance if } \\
\text { Item Deleted }\end{array}$ & $\begin{array}{c}\text { Corrected } \\
\text { Item-Total } \\
\text { Correlation }\end{array}$ & $\begin{array}{c}\text { Cronbach's } \\
\text { Alpha if Item } \\
\text { Deleted }\end{array}$ \\
\hline KSD1 & 33,05 & 3,785 &, 166 &, 727 \\
KSD2 & 33,24 & 2,972 &, 497 &, 614 \\
KSD3 & 33,25 & 2,795 &, 578 &, 579 \\
KSD4 & 33,11 & 3,493 &, 241 &, 698 \\
KSD5 & 18,95 & 1,018 & 1,000 &, 241 \\
\hline
\end{tabular}

Sumber : Data yang diolah, 2019

Berdasarkan tabel 3 maka dapat dilihat bahwa seluruh pernyataan untuk variabel metode Kesadaran Wajib Pajak memiliki status valid, karena nilai $\mathrm{r}$ hitung ( Connected Item Total Correlation > $\mathrm{r}$ tabel sebesar 0,165

Tabel 4

Uji Validitas Kepatuhan Wajib Pajak (Y)

Item-Total Statistics

\begin{tabular}{|l|r|r|r|r|}
\hline & $\begin{array}{c}\text { Scale Mean } \\
\text { if Item } \\
\text { Deleted }\end{array}$ & $\begin{array}{c}\text { Scale } \\
\text { Variance if } \\
\text { Item Deleted }\end{array}$ & $\begin{array}{c}\text { Corrected } \\
\text { Item-Total } \\
\text { Correlation }\end{array}$ & $\begin{array}{c}\text { Cronbach's } \\
\text { Alpha if Item } \\
\text { Deleted }\end{array}$ \\
\hline KPT1 & 40,82 & 8,412 &, 233 &, 738 \\
KPT2 & 40,39 & 7,755 &, 535 &, 689
\end{tabular}




\begin{tabular}{|l|r|r|r|r|} 
KPT3 & 40,65 & 7,543 &, 557 &, 680 \\
KPT4 & 40,50 & 7,364 &, 554 &, 675 \\
KPT5 & 40,59 & 7,578 &, 425 &, 700 \\
KPT6 & 22,55 & 2,331 & 1,000 &, 521 \\
\hline
\end{tabular}

Sumber : Data yang diolah, 2019

Berdasarkan tabel 4 maka dapat dilihat bahwa seluruh pernyataan untuk variabel metode Kepatuhan Wajib Pajak memiliki status valid, karena nilai $r$ hitung ( Connected Item Total Correlation > $\mathrm{r}$ tabel sebesar 0,165)

\section{Uji Reliabilitas}

Reliabilitas adalah alat untuk mengukur suatu kuesioner yang merupakan indikator dari variabel atau konstruk. Suatu kuesioner dikatakan reliabel atau handal jika jawaban seseorang terhadap pertanyaan adalah konsisten atau stabil dari waktu ke waktu. SPSS memberikan fasilitas untuk mengukur reliabilitas dengan uji statistik Cronbach Alpha $(\alpha)$. Suatu konstruki atau variabel dikatakan reliabel jika memberikan nilai $(\alpha) 0,60$.

Reliabilitasnya menggunakan rumus Cronbach Alpha. Pengujian validitas dilakukan dengan bantuan komputer menggunakan program SPSS for Windows Versi 23. Adapun realibilitas untuk masing-masing variable hasilnya disajikan dalam tabel berikut ini

Tabel 5

Hasil uji reliabilitas variabel Kualitas Pelayanan Pajak (X1) Reliability Statistics

\begin{tabular}{|r|r|}
\hline Cronbach's Alpha & N of Items \\
\hline, 680 & \\
\hline
\end{tabular}

Sumber : Data yang diolah, 2019

Tabel 6

Hasil uji reliabilitas variabel Sanksi Perpajakan (X2)

Reliability Statistics

\begin{tabular}{|r|c|}
\hline Cronbach's Alpha & N of Items \\
\hline, 687 & \\
\hline
\end{tabular}

Sumber : Data yang diolah, 2019

Tabel 7

Hasil uji reliabilitas variabel Kesadaran Wajib Pajak (X3) Reliability Statistics

\begin{tabular}{|r|r|}
\hline Cronbach's Alpha & N of Items \\
\hline, 682 & \\
\hline
\end{tabular}

Sumber : Data yang diolah, 2019

Tabel 8

Hasil uji reliabilitas variabel Kepatuhan Wajib Pajak (Y) Reliability Statistics

\begin{tabular}{|l|c|}
\hline Cronbach's Alpha & N of Items \\
\hline
\end{tabular}


\begin{tabular}{r|r|}
\hline, 725 & 6 \\
\hline
\end{tabular}

Sumber : Data yang diolah,2019

Berdasarkan hasil uji reliabilitas pada data diatas, maka dapat disimpulkan sebagai berikut :

a. Untuk variabel Kualitas Pelayanan Pajak (X1) nilai Cronbach's Alpha sebesar 0,680 dan lebih besar dari 0,6 maka variabel tersebut reliabel.

b. Untuk variabel Sanksi Perpajakan (X2) nilai Cronbach's Alpha sebesar 0,687 dan lebih besar dari 0,6 maka variabel tersebut reliabel.

c. Untuk variabel Kesadaran Wajib Pajak (X3) nilai Cronbach's Alpha sebesar 0,682 dan lebih besar dari 0,6 maka variabel tersebut reliabel.

d. Untuk variabel Kepatuhan Wajib Pajak (Y) nilai Cronbach's Alpha sebesar 0,725 dan lebih besar dari 0,6 maka variabel tersebut reliabel.

\title{
Uji Asumsi Klasik dan Uji Normalitas
}

\section{Uji Normalitas menggunakan metode Normal P-Plot}

Uji normalitas bertujuan untuk menguji apakah dalam model regresi, variabel pengganggu atau residual memiliki distribusi normal. Model regresi yang baik adalah memiliki distribusi data normal atau penyebaran data statistik pada sumbu diagonal dari grafik distribusi normal.

\author{
Gambar 1 \\ Hasil Uji Normalitas Data
}




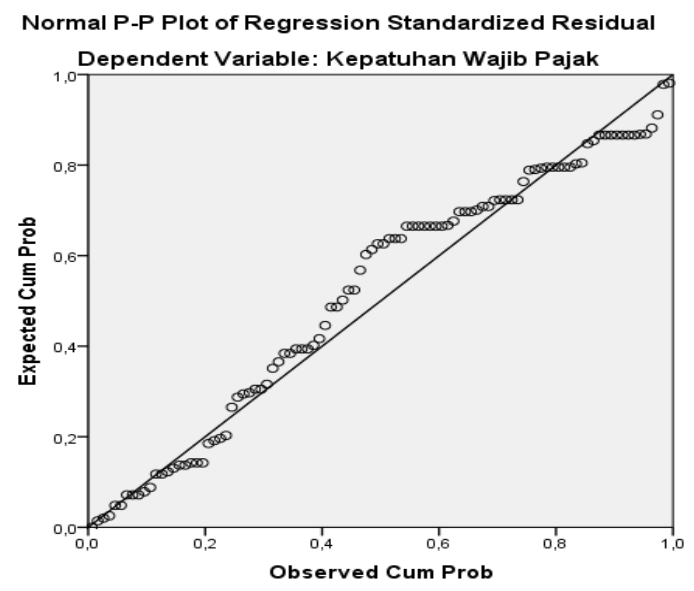

Dari gambar grafik pp plot diatas dapat diketahui bahwa grafik berada dibawah titik-titik yang menyebar sekitar garis dan mengikuti garis diagonal dengan ini maka data kuesioner terdistribusi secara normal.

Tabel 9

Hasil Uji Normalitas uji metode Kolmogorov-Smirnov Tests of Normality

\begin{tabular}{|l|r|r|r|r|r|r|}
\hline \multirow{2}{*}{} & \multicolumn{3}{|c|}{ Kolmogorov- } & \multicolumn{3}{c|}{ Shapiro-Wilk } \\
\cline { 2 - 7 } & $\begin{array}{c}\text { Statisti } \\
\mathrm{c}\end{array}$ & df & Sig. & Statistic & df & Sig. \\
\hline $\begin{array}{l}\text { Unstandardized } \\
\text { Residual }\end{array}$ &, 180 & 100 &, 079 &, 922 & 100 & $\begin{array}{r}09 \\
0\end{array}$ \\
\hline
\end{tabular}

a. Lilliefors Significance Correction

Sumber : Data yang diolah, 2019

Dari output diatas dapat diketahui bahwa nilai signifikansi (Sig) pada Kolmogorov-Smirnov sebesar 0,079. Karena nilai signifikansi lebih dari 0,05 maka residual terdistribusi dengan normal.

Tabel 10

\section{Hasil Uji Multikolinearitas}

Coefficients $^{\mathrm{a}}$ 


\begin{tabular}{|ll|r|r|}
\hline \multirow{2}{*}{ Model } & \multicolumn{2}{|c|}{ Collinearity Statistics } \\
\cline { 2 - 3 } & Tolerance & \multicolumn{1}{|c|}{ VIF } \\
\hline $1 \quad$ Constant) & & \\
& Kualitas Pelayanan &, 926 & 1,079 \\
& Sanksi Perpajakan &, 974 & 1,027 \\
& Kesadaran Wajib Pajak &, 934 & 1,070 \\
\hline
\end{tabular}

a. Dependent Variable: Kepatuhan Wajib Pajak

Dari data tabel 10 diatas dapat diketahui bahwa nilai VIF kurang dari 10 dan nilai tolerans lebih dari 0,1 untuk ketiga variabel maka dapat disimpulkan bahwa model regresi tidak terjadi masalah multikolinearitas.

\section{Uji Heterokedasititas}

Uji heteroskedastisitas dilakukan untuk menguji apakah dalam sebuah model regresi terjadi ketidaksamaan varians residual dari satu pengamatan ke pengamatan yang lain tetap, maka disebut Heteroskedastisitas. Jika titik-titik menyebar diatas dan dibawah angka 0 pada sumbu $\mathrm{Y}$ tanpa membentuk pola tertentu, maka tidak terjadi heteroskedastisitas (Ghozali, 2012)

\section{Gambar 2}

\section{Hasil Uji Heterokedasititas}

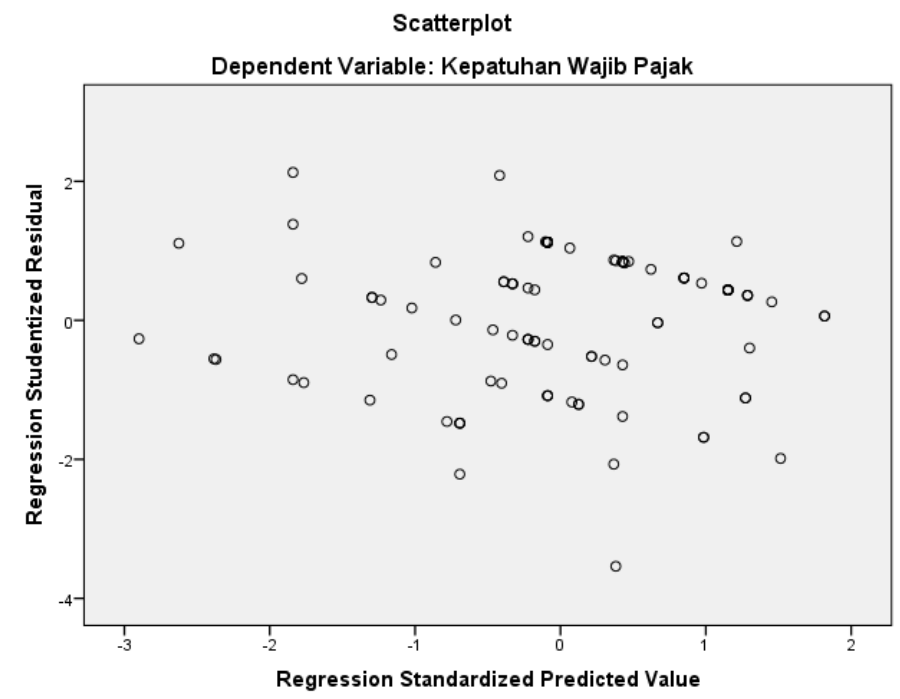

Berdasarkan gambar scatter plot diatas dapat diketahui bahwa titik - titik menyebar dengan pola yang tidak jelas diatas dan dibawah angka 0 (nol) pada sumbu y, maka jadi dapat disimpulkan tidak terjadi masalah heterokedastisitas pada model regresi.

\section{Uji Autokorelasi}

Uji autokorelasi bertujuan menguji apakah dalam model regresi linier ada korelasi antara kesalahan pengganggu pada periode $t$ dengan kesalahan pengganggu pada periode t-1 (sebelumnya). Jika terjadi korelasi, maka dinamakan ada problem autokorelasi. 
Pada penelitian ini untuk menguji ada tidaknya gejala autokorelasi menggunakan uji Durbin-Watson (DW test).

Tabel 11

Hasil Uji Autokorelasi

Model Summary ${ }^{b}$

\begin{tabular}{|l|c|r|r|r|r|}
\hline Model & R & R Square & $\begin{array}{c}\text { Adjusted R } \\
\text { Square }\end{array}$ & $\begin{array}{c}\text { Std. Error of } \\
\text { the Estimate }\end{array}$ & $\begin{array}{c}\text { Durbin- } \\
\text { Watson }\end{array}$ \\
\hline 1 &, $488^{\mathrm{a}}$ &, 238 &, 214 & 1,377 & 2,048 \\
\hline
\end{tabular}

a. Predictors: (Constant), Kesadaran Wajib Pajak, Sanksi Perpajakan,

Kualitas Pelayanan

b. Dependent Variable: Kepatuhan Wajib Pajak

Berdasarkan Tabel 11, dapat diketahui bahwa nilai Durbin Watson sebesar 2,048. Sedangkan dari tabel DW dengan signifikansi 0,05 dan jumlah data $(n)=100$, serta $k=3$ ( $\mathrm{k}$ adalah jumlah variable independen) diperoleh nilai dl sebesar 1,6131 dan du sebesar 1,7364 (lihat pada lampiran). Dengan ini maka didapat 4-du $=(4-1,7364)=2,2636$ dan $4-\mathrm{dl}=(4-1,6131)=2,3869$. Karena nilai DW 2,084 maka pengambilan keputusan pada uji Durbin Watson adalah du $<\mathrm{dw}<4$-du yaitu 1,736 < 2,084 < 4-1,7364 maka dapat disimpulkan bahwa tidak terjadi autokorelasi pada model regresi.

\section{Regresi Linear Berganda}

Analisis regresi berganda digunakan apabila kita ingin meramalkan pengaruh variabel dua buah variabel prediktor $(\mathrm{X})$ atau lebih terhadap suatu variabel kriterium $(\mathrm{Y})$ atau untuk membuktikan bahwa terdapat atau tidak terdapatnya hubungan fungsional antara dua buah variabel bebas (X) atau lebih dengan sebuah variabel terikat (Y). Untuk menentukan persamaan regresi dapat dilihat tabel dibawah ini:

Tabel 12

Hasil Uji Model Regresi Linear Berganda

Coefficients $^{\mathrm{a}}$ 


\begin{tabular}{|c|c|c|c|c|c|}
\hline \multirow[b]{2}{*}{ Model } & \multicolumn{2}{|c|}{$\begin{array}{c}\text { Unstandardized } \\
\text { Coefficients }\end{array}$} & \multirow{2}{*}{$\begin{array}{c}\text { Standardiz } \\
\text { ed } \\
\text { Coefficient } \\
\text { s }\end{array}$} & \multirow[b]{2}{*}{$\mathrm{t}$} & \multirow[b]{2}{*}{ Sig. } \\
\hline & $\mathrm{B}$ & $\begin{array}{c}\text { Std. } \\
\text { Error }\end{array}$ & & & \\
\hline 1 (Constant) & 2,563 & 3,695 & & 694 &, 490 \\
\hline $\begin{array}{l}\text { Kualitas } \\
\text { Pelayanan }\end{array}$ & ,412 & , 122 & ,312 & 3,369 & ,001 \\
\hline $\begin{array}{l}\text { Sanksi } \\
\text { Perpajakan }\end{array}$ & ,229 & ,079 & ,263 & 2,912 & ,004 \\
\hline $\begin{array}{l}\text { Kesadaran } \\
\text { Wajib Pajak }\end{array}$ & ,401 & , 140 & ,265 & 2,872 &, 005 \\
\hline
\end{tabular}

a. Dependent Variable: Kepatuhan Wajib Pajak

$\mathrm{Y}=\alpha+\beta 1 \mathrm{X} 1+\beta 2 \mathrm{X} 2+\beta 3 \mathrm{X} 3+\beta 4 \mathrm{X} 4+\varepsilon$

$Y=2,563+0,412 X 1+0,229 X 2+0,401 X 4$

\section{Keterangan :}

Berdasarkan hasil analisis model regresi linier berganda maka penjelasannya sebagai berikut :

1. Konstanta sebesar 2,563 ; artinya jika kualitas pelayanan pajak, sanksi perpajakan, kesadaran wajib pajak nilainya 0 , maka kepatuhan wajib pajak nilainya sebesar 2,563 .

2. Koefisien regresi variabel kualitas pelayanan pajak sebesar 0,412 ; artinya jika kualitas pelayanan pajak mengalami kenaikan satu satuan, maka kepatuhan wajib pajak mengalami peningkatan sebesar 0,412 satuan dengan asumsi variabel indepeden yang lainnya bernilai tetap.

3. Koefisien regresi variabel sanksi perpajakan sebesar 0,229 ; artinya jika sanksi perpajakan mengalami kenaikan satu satuan, maka kepatuhan wajib pajak mengalami peningkatan sebesar 0,229 satuan dengan asumsi variabel indepeden yang lainnya bernilai tetap.

4. Koefisien regresi variabel kesadaran wajib pajak sebesar 0,401 ; artinya jika kesadaran wajib pajak mengalami kenaikan satu satuan, maka kepatuhan wajib pajak mengalami peningkatan sebesar 0,401 satuan dengan asumsi variabel indepeden lainnya bernilai tetap.

Diantara ketiga variabel independen yang ada, variabel kualitas pelayanan pajak yang memiliki pengaruh paling besar terhadap kepatuhan wajib pajak, yaitu 0,412

\section{Uji Hipotesis}

Uji statistik (Uji F) bertujuan untuk mengetahui pengaruh secara bersama-sama atau simultan variabel independen terhadap variable dependen atau terikat. Untuk melaksanakan uji F pada variabel kualitas pelayanan pajak (X1), sanksi perpajakan (X2), 
kesadaran wajib pajak (X3) dan kepatuhan wajib pajak (Y), dapat dilakukan langkahlangkah sebagai berikut:

a. Hipotesis.

Ho : Tidak ada pengaruh kualitas pelayanan pajak, sanksi perpajakan, kesadaran wajib pajak secara bersama-sama tidak berpengaruh terhadap kepatuhan wajib pajak

Ha : Tidak ada pengaruh kualitas pelayanan pajak, sanksi perpajakan, kesadaran wajib

b. Tabel Fhitung pajak secara bersama-sama berpengaruh terhadap kepatuhan wajib pajak

\section{Tabel 13}

Hasil Uji F

ANOVA ${ }^{a}$

\begin{tabular}{|l|r|r|r|r|r|}
\hline Model & \multicolumn{1}{|c|}{$\begin{array}{c}\text { Sum of } \\
\text { Squares }\end{array}$} & Df & \multicolumn{1}{c|}{$\begin{array}{c}\text { Mean } \\
\text { Square }\end{array}$} & F & Sig. \\
\hline 1 Regression & 56,886 & 3 & 18,962 & 10,004 &, $000^{\mathrm{b}}$ \\
Residual & 181,954 & 96 & 1,895 & & \\
Total & 238,840 & 99 & & & \\
\hline
\end{tabular}

a. Dependent Variable: Kepatuhan Wajib Pajak

b. Predictors: (Constant), Kesadaran Wajib Pajak, Sanksi Perpajakan,

Kualitas Pelayanan

c. Ftabel

Tabel distribusi $\mathrm{F}$ dicari pada $\mathrm{a}=5 \%$ atau dengan probabilitas 0,05 , $\mathrm{df}=\mathrm{n}-\mathrm{k}-1=100$ - 3 - 1 = 96 ( $\mathrm{n}$ adalah jumlah data dan $\mathrm{k}$ adalah jumlah variabel independen). Dengan pengujian signifikansi (probabilitas 0,05) hasil diperoleh untuk Ftabel $=$ F0,5 (96) $=$ sebesar 2,696

Karena nilai Fhitung > Ftabel atau $(10,004>2,696)$ dan nilai signifikansinya 0,000 lebih kecil dari dari probabilitas signifikan $\alpha=0,05$, maka Ho ditolak Ha diterima, artinya bahwa kualitas pelayanan pajak, sanksi perpajakan, dan kesadaran wajib pajak secara simultan berpengaruh terhadap kepatuhan wajib pajak.

\section{KESIMPULAN}

Berdasarkan analisis data dapat disimpulkankan bahwa variabel kualitas pelayanan pajak, sanksi perpajakan, dan kesadaran wajib pajak berpengaruh secara bersama - sama terhadap variabel kepatuhan wajib pajak. Hasil tersebut menunjukkan bahwa semakin meningkat kualitas pelayanan yang diberikan, meningkatnya sanksi perpajakan, serta meningkatnya kesadaran wajib pajak maka wajib pajak akan lebih patuh dalam menunaikan kewajiban pajak kendaraan bermotornya.

\section{Buku}

\section{DAFTAR PUSTAKA}

Agoes, Sukrisno, Estralita Trisnawati. 2014. Akuntansi Perpajakan (Edisi 3). Jakarta. Salemba 4. 
Anatan, Lina dan Ellitan, Lena. 2007. Manajemen Sumber Daya Manusia Dalam Bisnis Modern. Bandung, Alfabeta.

Burhanudin, N . 2010. Mushaf Al Burhan, Edisi I. Kutai. Media Fitrah Rabbani.

Hartati, Neneng. 2015. Pengantar Perpajakan. Jakarta. Pustaka Setia.

Imam, Ghozali. 2013. Multivariate Analysis, SPSS. Semarang. Universitas Diponegoro.

Mulyono, Djoko. 2010. Hukum Pajak Konsep, Aplikasi, Dan Penuntun Prakti. Yogyakarta. CV. ANDI.

Mardiasmo, Dr. Prof. 2012. Perpajakan, Edisi Revisi. Yogyakarta. CV ANDI.

Rahayu, Siti Kurnia. 2013. Perpajakan Indonesia (Konsep dan Aspel Formal). Yogyakarta: CV Andi.

Resmi, Siti. 2014. Perpajakan (Teori \& Kasus),Edisi ke-6. Jakarta. Salemba Empat.

Sari, Diana, Dr. Prof. 2014. Perpajakan, Konsep, Teori, Dan Aplikasi Pajak Penghasilan. Edisi Asli. Jakarta. Mitra Wacana Media.

Sugiyono, Dr. Prof. 2014. Metode Penelitian Kuantitatif, Kualitatif, Dan R\&D. Bandung. CV Alvabeta.

Tjiptono. 2016. Manajemen Pemasaran 2, Manajemen Jasa. Yogyakarta. Andi.

Waluyo. 2012. Perpajakan Indonesia. Buku 1. Jakarta. Salemba Empat.

\section{Jurnal}

Aini, Qurrotul. 2013. Peran E-Registration Terhadap Tingkat Kepatuhan Wajib Pajak Orang Pribadi (Studi Kasus di KPP Pratama Surabaya). Jurnal Akuntansi Unesa. Vol.2, No.1.

Alvin, Aloysius. 2014. Pengaruh Sikap, Norma Subyektif, Dan Kontrol Perilaku Yang Dipresepsikan Staff Pajak Terhadap Kepatuhan Pajak Wajib Pajak Badan. Jurnal Tax Accounting Review, Vol. 4, No.1.

Amanda, Cynthia Pradisti, Dandes Rifa \& Minovia, Arie Frinola. 2014. Pengaruh Kesadaran Wajib Pajak, Sanksi Pajak, Pelayanan Fiskus dan Pemeriksaan Pajak Terhadap Kepatuhan Wajib Pajak Orang Pribadi di Kota Padang. Jurnal Akuntansi. Vol.4, No. 1.

Arum. Harjanti Puspa. 2014. Pengaruh Kesadaran Wajib Pajak, Pelayanan Fiskus, dan Sanksi Pajak Terhadap Kepatuhan Wajib Pajak Orang Pribadi Yang Melakukan 
Kegiatan Usaha dan Pekerjaan Bebas. Diponegoro Journal Of Accounting. Vol.1, No.1:1-8.

Febrian, Adhitya Arifin. 2015. Pengaruh Modernisasi Sistem Administrasi Perpajakan, Kesadaran Perpajakan, Sanksi Pajak dan Pelayanan Fiskus Terhadap Kepatuhan Wajib Pajak Orang Pribadi Pada KPP Pratama. Jurnal Akuntansi Perbanas Review, Vol.1, No.1.

Hidayat, Widi. 2013. Study Empiris Theory Of Planned Behavior Dan Pengaruh Kewajiban Moral Pada Perilaku Ketidakpatuhan Pajak Wajib Pajak Orang Pribadi. Jurnal Akuntansi dan Keuangan, Vol. 12, No.2.

Jokopurnomo, Cindy dan Mangoting, Yenni. 2013. Pengaruh Kesadaran Wajib Pajak, Kualitas Pelayanan Fiskus, Sanksi Perpajakan, Lingkungan Wajib Pajak Terhadap Kepatuhan Wajib Pajak Orang Pribadi di Surabaya. Jurnal Tax \& Accounting Review, Vol.1, No.1.

Jounice, Z.S.W., J.J. Soundakh., S.K. Waldandouw. 2015. Pengaruh Sosialisasi Perpajakan Dan Sanksi Perpajakan Terhadap Kepatuhan Pelaporan SPT Tahunan Wajib Pajak Badan (Studi Kasus Pada KPP Pratama Manado Dan KPP Pratama Bitung). Jurnal Riset Ekonomi, Manajemen, Bisnis dan Akutansi. Vol.3, No.4.

Kiryanto. 2000. Analisis Pengaruh Penerapan Struktur Pengendalian Intern Terhadap Kepatuhan Wajib Pajak Badan Dalam Memenuhi Kewajiban Pajak Penghasilannya. EKOBIS, Vol. 1.

Muliari, Ni Ketut dan Putu Ery Setiawan. 2011. Pengaruh Persepsi Tentang Sanksi Perpajakan dan Kesadaran Wajib Pajak Pada Kepatuhan Pelaporan Wajib Pajak Orang Pribadi Di Kantor Pelayanan Pajak Pratama Depansar Timur. Jurnal Akuntansi dan Bisnis, Volume 2.

Mutia, Sri Putri Tita. 2014. Pengaruh Sanksi Perpajakan, Kesadaran Perpajakan, Pelayanan Fiskus, dan Tingkat Pemahaman Terhadap Kepatuhan Wajib Pajak Orang Pribadi (Studi Empiris pada Wajib Pajak Orang Pribadi yang terdaftar di KPP Pratama Padang). Jurnal Akuntansi, Vol.1.

Putri, Amanda R. Siswanto dan Jati, I Ketut, 2012. Faktor-Faktor Yang Mempengaruhi Kepatuhan Wajib Pajak Dalam Membayar Pajak Kendaraan Bermotor Di Denpasar. Jurnal Fakultas Ekonomi Universitas Udayana Bali.

Suryani, Lilis. 2017. Pengaruh Sikap, Norma Subyektif, Dan Kontrol Perilaku Persepsian Terhadap Kepatuhan Wajib Pajak Orang Pribadi Di Daerah Istimewa Yogyakarta Dengan Niat Mematuhi Pajak Sebagai Variabel Pemoderasi. Jurnal Akuntansi dan Pendidikan, Edisi 3. 
Tiraada, A.M. Tryana. 2013. Kesadaran Perpajakan, Sanksi Pajak, Sikap Fiskus Terhadap Kepatuhan Wajib Pajak Orang Pribadi di Kabupaten Minahasa Selatan. Jurnal Riset Ekonomi, Manajemen, Bisnis dan Akutansi, Volume 1 No.3.

Winerungan, Oltaviane Lidya. 2013. Sosialisasi Perpajakan, Pelayanan Fiskus dan Sanksi Perpajakan Terhadap Kepatuhan Wajib Pajak Orang Pribadi di KPP Manado dan KPP Bitung. Jurnal Riset Ekonomi, Manajemen, Bisnis dan Akuntansi, Vol.1, No.3.

Yuliana, Rita., Isharijadi. 2014. Pengaruh Sikap, Norma Subyektif, Dan Keadilan Pajak Terhadap Kepatuhan Wajib Pajak Orang Pribadi Di KPP Pratama Madiun. Jurnal Akuntansi dan Pendidikan, Vol. 3, No. 2.

$\underline{\text { Internet }}$

Http://www.pajak.go.id/sites/deflaut/files/19_PMK.03-2019.per.pdf (diunduh pada Tanggal 10 Mei 2019 Pukul 10.25 WIB).

http://www.pajak.go.id/article (diunduh pada Tanggal 10 Mei 2019 Pukul 14.10 WIB).

http://www.pajak.go.id/article/sudah-cukupkah-kepatuhan-pajak-kita (diunduh pada Tanggal 10 Mei 2019 Pukul 14.15 WIB).

http://ketentuan.pajak.go.id/index.php?r=aturan/rincian\&idcrypt=oJeloaQ\%3D (diunduh pada Tanggal 10 Mei 2019 Pukul 21.02 WIB).

https://kbbi.web.id/norma (diunduh pada Tanggal 11 Mei 2019 Pukul 08.48 WIB).

https://kbbi.web.id/kesadaran (diunduh pada Tanggal 11 Mei 2019 Pukul 09.00 WIB).

https://id.wikipedia.org/wiki/Skala_Likert (diunduh pada Tanggal 25 Mei 2019 Pukul 09.20 WIB). 